\title{
Determination of the diffusion of monovalent cations into wood under isothermal conditions based on $\mathrm{LiCl}$ impregnation of Norway spruce
}

\begin{abstract}
The impregnation of wood pieces in the course of pulping can be divided into primary (advective mass transport) and secondary (diffusive mass transport) penetration. Little is known about the latter partly because of the difficulties in the determination of the relevant diffusivities for this system. In the present article, a precise experimental methodology has been developed to measure the concentration profiles of cations as a function of wood piece dimensions, impregnation time, temperature, and wood structure. The cation concentration can be measured at any position in the impregnated wood piece. The impregnation of Norway spruce wood samples with $\mathrm{LiCl}$ was investigated. The impregnated wood pieces were cut mechanically into cubes, which were cut in slices by means of a microtome, and the eluate of the 0.4-mm-thick slices in $\mathrm{HNO}_{3}$ was analyzed by flame atomic emission spectroscopy. The method gave reasonable results, and defects in the wood piece (microcracks) were detectable. The preliminary results presented here have to be verified with more replicates due to the heterogeneity of wood.
\end{abstract}

Keywords: diffusion, experimental methodology, impregnation, lithium chloride, local concentration, Norway spruce

*Corresponding author: Hans Theliander, Division of Forest Products and Chemical Engineering, Department of Chemical and Biological Engineering, Chalmers University of Technology, SE-41296 Gothenburg, Sweden, Phone: +46317722992, Fax: +46317722995, e-mail: hanst@chalmers.se

Reddysuresh Kolavali: Division of Forest Products and Chemical Engineering, Department of Chemical and Biological Engineering, Chalmers University of Technology, SE-41296 Gothenburg, Sweden

\section{Introduction}

Lignocellulosic biomass is the most abundant renewable material, accounting for $50 \%$ of all the biomass in the world, and its rational utilization helps preserve fossil resources (Classen et al. 1999; Fernando et al. 2006). The most popular keyword in this context is "biorefinery". It refers to petroleum refinery as a model for perfect utilization, which produces various types of fuels and materials from petroleum. The pulping industry is the most developed chemical technology of wood, and biorefinery intends to establish further improvements in this area to produce fuels, power, heat, and value-added chemicals from biomass. It is believed that biorefinery will play a significant role in forest clusters worldwide (Näyhä and Pesonen 2012). There are huge research efforts in the field of biorefinery aiming at the production of value-added products (Ragauskas et al. 2006; Dautzenberg et al. 2011; Gütsch and Sixta 2011; Hörhammer et al. 2011; Kirsch et al. 2011; López et al. 2011; Martin-Sampedro et al. 2011; Schütt et al. 2011; Testova et al. 2011). For example, the extraction of a portion of hemicelluloses from wood before pulping - by acid hydrolysis, autohydrolysis, steam explosion, or alkali extraction - seems to be promising in this context. In any case, the impregnation of wood with chemicals will be of great importance for the economically viable biorefinery. The goal is a uniform distribution of moisture and chemicals within the wood pieces at the very beginning of the main reaction. This is the reason why the complex chemical transport phenomena of reactants via lumina and voids to the solid matrix must be understood better.

Most of the investigations are based on either average flux measurement of the diffusing substance or electrical conductivity measurement of the impregnated wood samples. These methods have limitations and are not suitable to determine the concentration profiles. The most relevant investigations in this context have been identified (Cady and Williams 1935; Stamm 1946; Burr and Stamm 1947; Christensen 1951a,b; Christensen and Williams 1951; Narayanamurti and Ratra 1951; Behr et al. 1953; Narayanamurti and Kumar 1953; Stone and Green 1959; Fukuyama and Urakami 1980, 1982, 1986; Siau 1984; Bengtsson and Simonson 1988; Robertsen 1993; Meijer et al. 1996; Sharareh et al. 1996; Kazi et al. 1997; Cooper 1998; Ra et al. 2001; Törnqvist et al. 2001; Gindl et al. 2002; Tsuchikawa and Siesler 2003; Jacobson et al. 2006). There is no standard method for measuring diffusion into wood.

There are many aspects of diffusion of chemicals into wood that have not yet been extensively studied. For 
example, most of the research on cation diffusion measurements into wood was conducted with $\mathrm{NaCl}, \mathrm{KCl}$, and $\mathrm{NaOH}$. In the case of $\mathrm{NaCl} / \mathrm{KCl}$ as diffusing substances, the high natural contents of $\mathrm{Na}^{+} / \mathrm{K}^{+}$ions in wood aggravate the measurements. In the case of $\mathrm{NaOH}$, the reactions of $\mathrm{OH}^{-}$ ions with wood components are masking the pure diffusion effects of $\mathrm{Na}^{+}$.

The present work is focusing on the diffusional mass transfer of cations into wood by considering some of these factors mentioned above. The intention is to determine the concentration profiles of cations within the wood pieces as a function of wood piece dimensions, impregnation time, wood structure, and temperature. Lithium chloride ( $\mathrm{LiCl})$ was chosen as agent and the $\mathrm{Li}^{+}$ion concentration was measured by flame atomic emission spectroscopy (FAES). The effects of genuine $\mathrm{Li}^{+}$and $\mathrm{Cl}^{-}$in the cell wall are negligibly small for the impregnation results. Su et al. (2012) demonstrated that $\mathrm{Li}^{+}$has a low affinity toward wood components.

\section{Materials and methods}

\section{Samples}

The stemwood disc with $23 \mathrm{~cm}$ thickness (without bark) of a 31 \pm 1 -yearold Norway spruce (Picea abies L.) was investigated. Both sapwood (sW) and heartwood (hW) samples were carefully prepared using a vertical band sawing machine (Mossner Rekord, August Mössner KG, Mutlangen, Germany; metal cutting band saw: L.S. Starrett Co., Ltd., Jedburgh, UK, with 14 teeth per inch) and kept preliminarily in an airtight polyethylene (PE) bag at $1^{\circ} \mathrm{C}$. It was assumed that the stemwood disc contains $50 \% \mathrm{sW}$ and $30 \% \mathrm{hW}$, and the remaining $20 \%$ is an intermediate between sW and hW (Sandberg and Sterley 2009). Only sW and hW were investigated and not the intermediate material. Only rot-free and other deformation-free samples were selected and cut into a rectangular prototype pieces using the same vertical band sawing machine mentioned above. Two different dimensions were prepared: $100 \times 25 \times 8$ and $100 \times 50 \times 4 \mathrm{~mm}^{3}(\mathrm{~L} \times \mathrm{R} \times \mathrm{T})$. Then, the material was stored in an airtight $\mathrm{PE}$ bag in a freezer at $-18^{\circ} \mathrm{C}$. Figure 1 illustrates the further procedure including the impregnation with $\mathrm{LiCl}$ (impregnation times: 1, 4, and $12 \mathrm{~h}$ ) and AES.

\section{Water impregnation cycles}

The defrosting of the wood pieces took $24 \mathrm{~h}$. Then, the pieces were water impregnated in a vacuum-pressure cycle. This was performed in a small polypropylene (PP) beaker placed in an autoclave filled with deionized water (at $\sim 22^{\circ} \mathrm{C}$; i.e., at room temperature). Then, vacuum was applied for $30 \mathrm{~min}$ and the autoclave was pressurized with $\mathrm{N}_{2}$ at $0.5 \mathrm{MPa}$ for $1 \mathrm{~h}$. This procedure was repeated until no floating pieces were observed after the complete water impregnation (a maximum of 3-5 cycles for sW and 5-10 cycles for hW were needed).

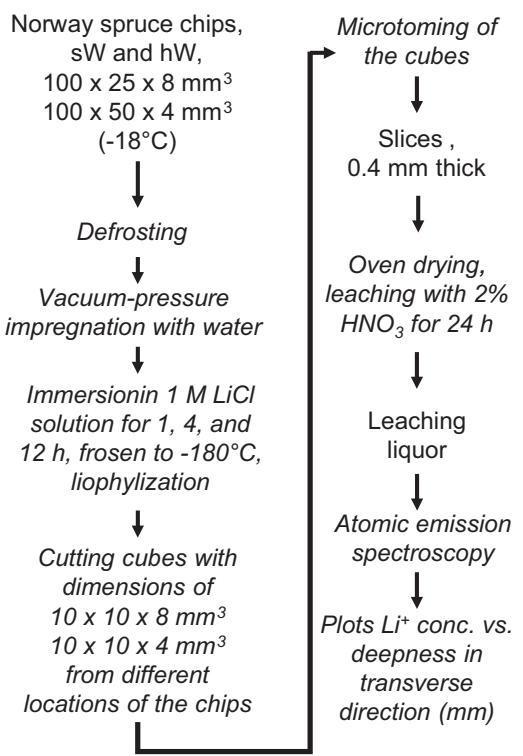

Figure 1 Scheme of the experimental design of this study.

To eliminate the small bubbles left on the surfaces (possible barriers against chemical diffusion), the pieces were kept in final vacuum for $30 \mathrm{~min}$ before the subsequent experimental steps.

\section{Impregnation with $\mathrm{LiCl}$}

The pieces were dabbed with filter paper and immersed in a solution of $1 \mathrm{M} \mathrm{LiCl}$ (Merck KGaA, Darmstadt, Germany) at a wood-to-liquor ratio of 1:50 (Figure 2). The impregnation vessel was made of PP and equipped with a liquor mixer (IKA, Staufen, Germany) fitted with a three-blade impeller (IKA, Staufen, Germany) to avoid the concentration gradients in the impregnation vessel. After 1,4 , and $12 \mathrm{~h}$ of

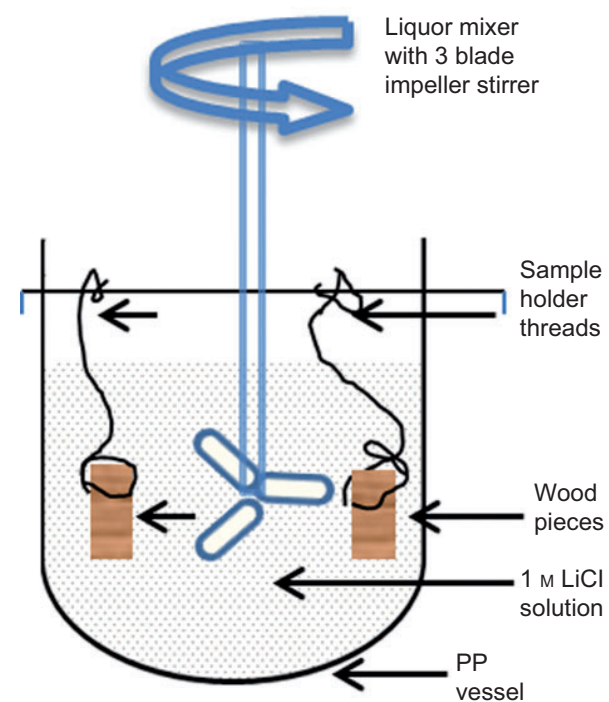

Figure 2 Experimental setup for impregnation with $\mathrm{LiCl}$ solution. 


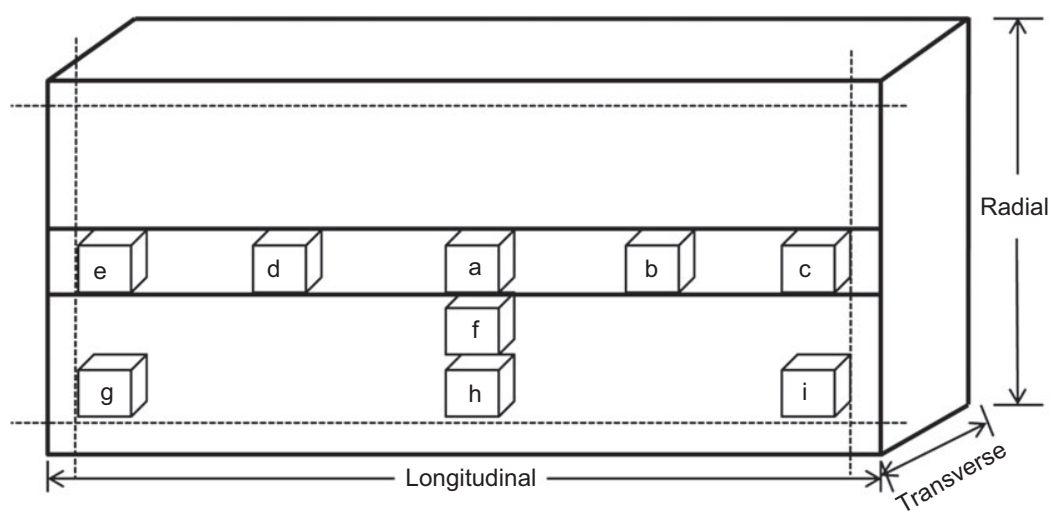

Figure 3 Sampling of small cubes with dimensions of $10 \times 10 \times 4 \mathrm{~mm}^{3}$ from an idealized wood piece (size $\sim 100 \times 50 \times 4 \mathrm{~mm}^{3}$ ), which were microtomed for $\mathrm{Li}^{+}$concentration profile measurements.

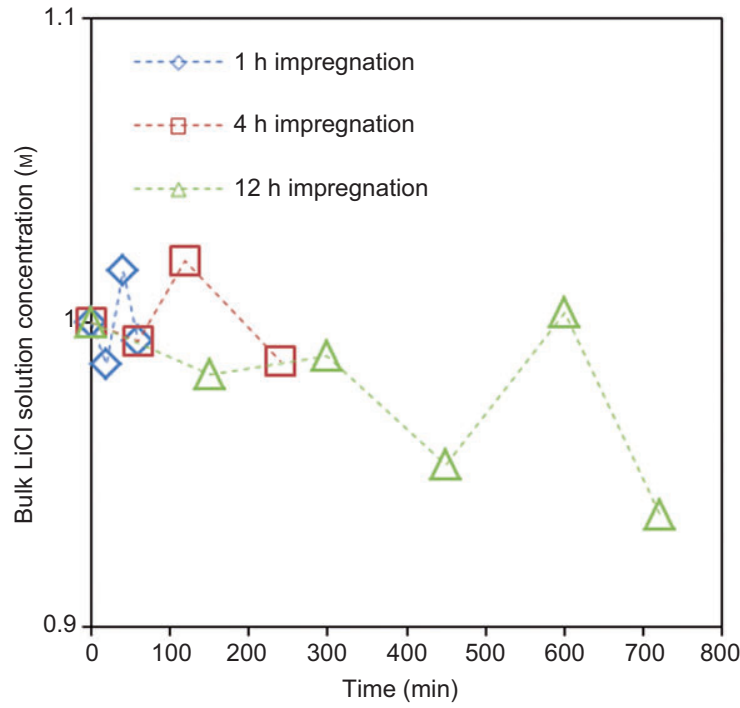

Figure 4 Variation of bulk $\mathrm{LiCl}$ solution concentration with time during the impregnation experiments at room temperature.

impregnation times, the pieces were removed and placed into liquid $\mathrm{N}_{2}\left(-180^{\circ} \mathrm{C}\right)$ to stop (minimize) the further migration of $\mathrm{Li}^{+}$. The frozen pieces were lyophilized (instrument: Labconco, Kansas City, MO, USA) for $\sim 2$ weeks. The drying procedure was controlled with parallel samples, the weights of which were measured.

\section{Flame atomic emission spectroscopy}

Each of the impregnated wood pieces was cut into small cubes (Figure 3) by means of a vertical band sawing machine (Mossner Rekord, August Mössner KG, Mutlangen, Germany; metal cutting band saw: L.S. Starrett Co., Ltd., Jedburgh, UK, with 14 teeth per inch). Cube dimensions: $10 \times 10 \times 8$ and $10 \times 10 \times 4 \mathrm{~mm}^{3}$ for $1 \mathrm{~h}$ impregnation experiments and $5 \times 5 \times 8$ and $5 \times 5 \times 4 \mathrm{~mm}^{3}$ in 4 and $12 \mathrm{~h}$ impregnation experiments. Each cube was microtomed in transverse direction to slices of $\sim 0.4 \mathrm{~mm}$ thickness, which were oven dried at $105^{\circ} \mathrm{C}$ for $1 \mathrm{~h}$. The dried slices were kept in desiccators containing blue gel salt and at room temperature. The slices were acid leached at room temperature with $2 \% \mathrm{HNO}_{3}$ (Mallinckrodt Baker, Inc., Phillipsburg,
NJ, USA) for $\sim 24 \mathrm{~h}$. A set of leaching experiments was also conducted for $72 \mathrm{~h}$ and there was no difference in the release of $\mathrm{Li}^{+}$ion between the 24 and $72 \mathrm{~h}$ leaching experiments. At the end of the leaching period, leaching liquor was collected with a syringe connected to $0.45 \mu \mathrm{m}$ polyvinylidene fluoride membrane filter (Pall Life Sciences, Ann Arbor, MI, USA). The leaching liquor was analyzed for $\mathrm{Li}^{+}$ion

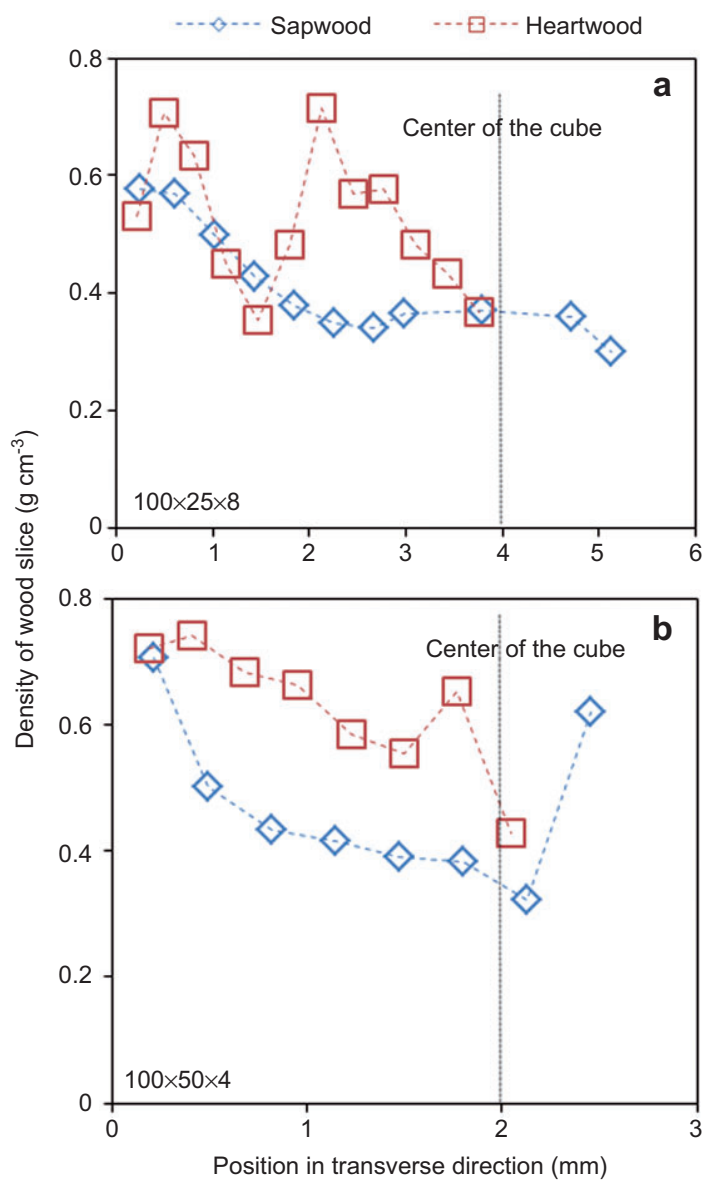

Figure 5 Density profiles for cube a (cf. Figure 3) of both sW and hW samples:

(a) $100 \times 25 \times 8 \mathrm{~mm}^{3}$ piece and (b) $100 \times 50 \times 4 \mathrm{~mm}^{3}$ piece. 


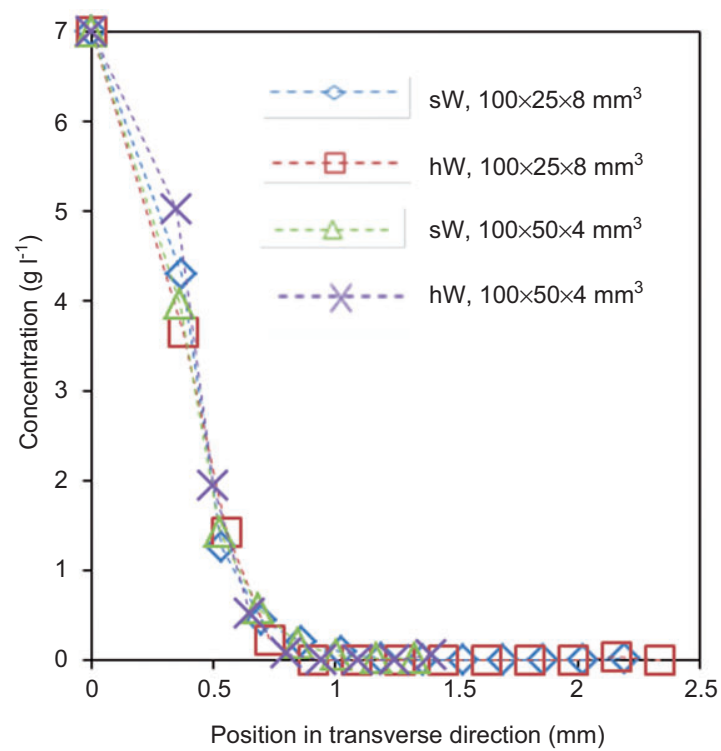

Figure 6 Measured concentration profiles of $\mathrm{Li}^{+}$ion in Norway spruce wood pieces at room temperature: sW vs. hW, $1 \mathrm{~h}$ impregnation time. concentration by FAES (iCE 3000 series, AA spectrometer; Thermo Scientific, Cambridge, UK). Air-acetylene was the flame source, and the emission was measured at $670.8 \mathrm{~nm}$. The $\mathrm{Li}^{+}$ion concentration was adjusted to an optimal working concentration range of $0.02-5$ $\mu \mathrm{g} \mathrm{ml}^{-1}$.

\section{Results and discussion}

The uniformity of the bulk $\mathrm{LiCl}$ concentration in the impregnation vessel was measured at different time intervals during the chemical impregnation experiments (Figure 4). This figure illustrates that, in all experiments with 1,4 , and $12 \mathrm{~h}$ impregnation times, the wood pieces were uniformly exposed to the constant bulk concentration of $1 \mathrm{M} \mathrm{LiCl}$.

The concentration of the chemical agent at the center of the wood piece is a measure of the completeness of wood treatment. Therefore, most of the data reported in

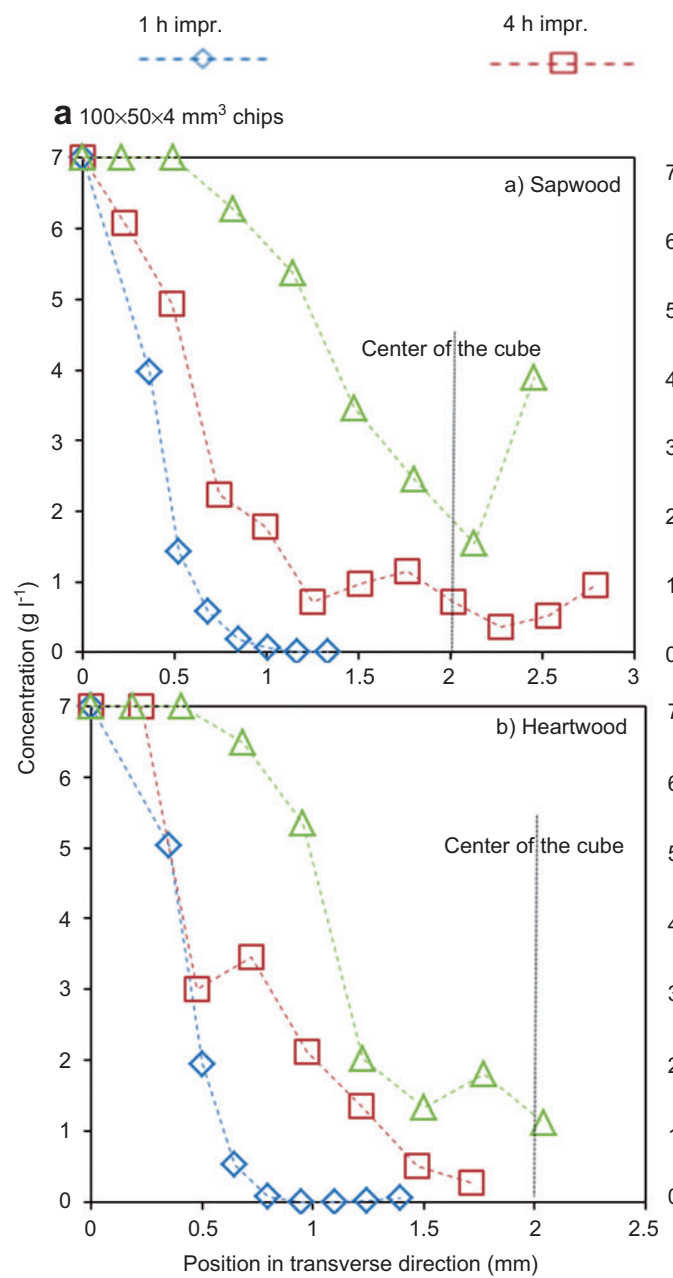

b $100 \times 25 \times 8 \mathrm{~mm}^{3}$ chips
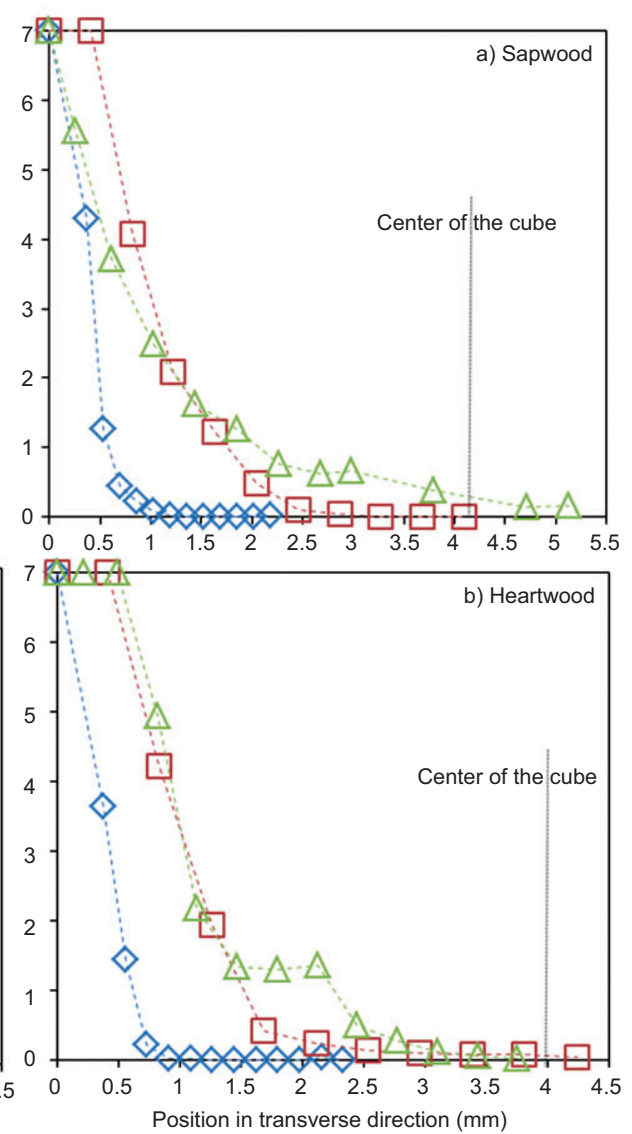

Figure 7 Measured concentration profiles of Li+ ${ }^{+}$ion in Norway spruce wood pieces at room temperature for two dimensions (as indicated) as a function of impregnation time. 


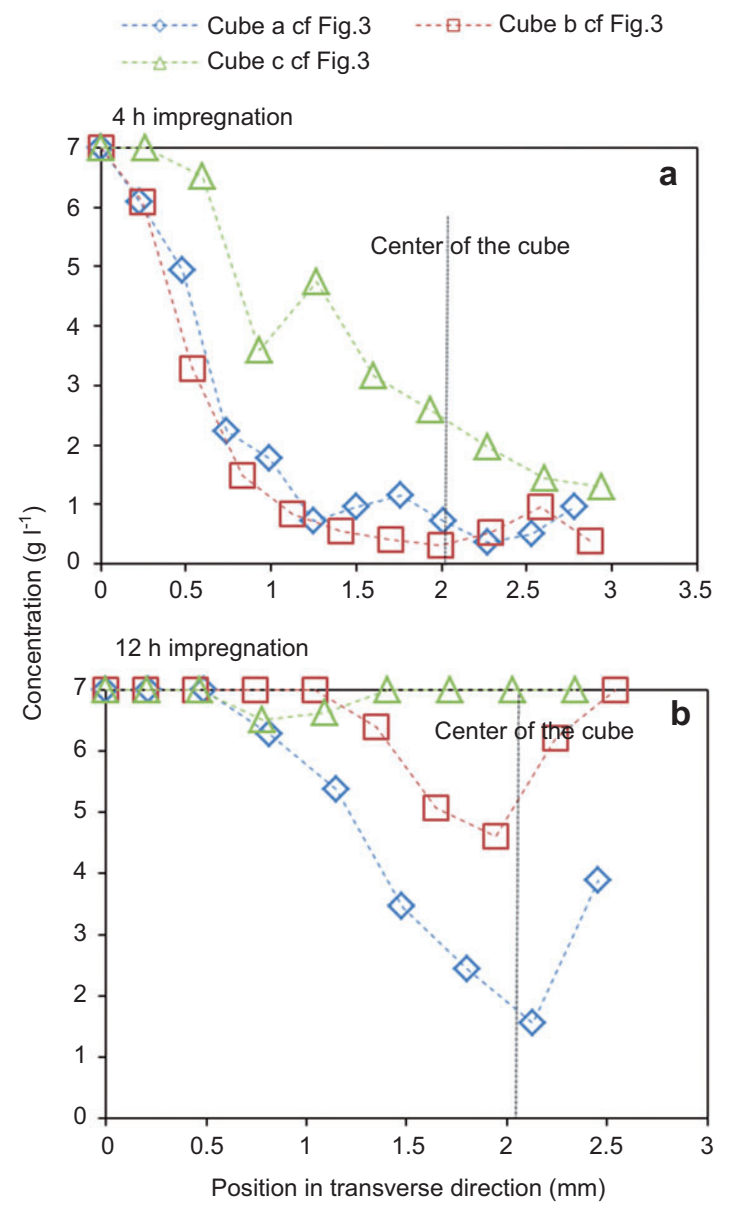

Figure 8 Measured concentration profiles of $\mathrm{Li}^{+}$ion in Norway spruce sW specimen at room temperature for $100 \times 50 \times 4 \mathrm{~mm}^{3}$ piece for 4 and $12 \mathrm{~h}$ impregnation times. a, b, and c refer to the sampling within the wood pieces (cf. Figure 3).

the present article are taken from cube a, which is from the center portion of the piece (Figure 3). In the course of the experiments, the density profiles were also determined in addition to the main concentration profiles. The parameter density is important because earlywood and latewood have different densities, which affect the transport of ions. The density profiles were measured for cube a (Figure 3) of both sW and hW samples with two dimensions (Figure 5). As expected, earlywood and latewood show lower and higher densities, respectively (Jyske et al. 2008). However, the density variation in $\mathrm{hW}$ is not consistent compared with sW due to its different chemical composition; for example, the extractive content in $\mathrm{hW}$ is higher.

In all the concentration profiles in this section, the concentration ( $\mathrm{g}$ of $\mathrm{Li}^{+} \mathrm{L}^{-1}$, where $\mathrm{L}$ is free volume of dried wood slice) is plotted against the position in the transverse direction of the specimens. These data describe the diffusional mass transport, that is, the assumption was that the mass transfer occurs through lumens and pits filled with water.

\section{Effect of impregnation time}

A very similar $\mathrm{Li}^{+}$ion concentration profile was observed in both sW and hW (Figure 6) during $1 \mathrm{~h}$ impregnation time. Indeed, there is a diffusional mass transport of $\mathrm{Li}^{+}$ions into the wood pieces. The $\mathrm{Li}^{+}$concentration difference between $\mathrm{sW}$ and $\mathrm{hW}$ is within the experimental error for FAES in the eluates. However, it should be kept in mind that the penetration depth observed in this study was $<1 \mathrm{~mm}$. Thus, the similarities between the concentration profiles in Figure 6 are the situation in layers close to the surface. Probably, the surface is modified in the course of sample preparation; for example, many microcracks may have formed, which affect the diffusion of $\mathrm{Li}^{+}$ions into deeper layers.

In Figure $7 \mathrm{a}$ and $\mathrm{b}$, a shift of $\mathrm{Li}^{+}$ion concentration profiles is visible after $12 \mathrm{~h}$ impregnation toward the center in $\mathrm{sW}$ and $\mathrm{hW}$ pieces with 4 and $8 \mathrm{~mm}$ thicknesses. For the 4-mm-thick piece (Figure 7a), the shapes of the concentration profiles are similar to that, which can be expected in a diffusional operation. Also for the 8-mm-thick piece (Figure $7 \mathrm{~b}$ ), the $1 \mathrm{~h}$ impregnated wood piece seems to be reasonable, but after 4 and $12 \mathrm{~h}$ impregnation times the concentration profiles have quite different shapes. One possible reason is that microcracks present in the wood pieces may have contributed to a better accessibility for $\mathrm{Li}^{+}$ ions to diffuse further into the interior of wood pieces, with increased impregnation time. This observation is much more pronounced in 4-mm-thick pieces compared with 8-mm-thick pieces for the same experimental conditions. This example demonstrates the relevance of local concentration measurements in comparison with data based on average properties. The spatial resolution of penetration is even indicative for microcracks otherwise not visible.

\section{Concentration profiles at various locations}

In Figure 8, the concentration profiles for three different positions (a, b, and c in Figure 3) are shown. Here, it is evident that the concentration profiles for cube $\mathbf{a}$ (middle) and cube $\mathbf{b}$ (between the middle and the end of the piece) were quite similar, and in these two cases, the diffusion of $\mathrm{Li}^{+}$ion was only influenced by mass transport in transversal direction. However, in the case of cube $\mathbf{c}$ (at the edge of the piece), the concentration profile is different because of the influence of mass transport in longitudinal direction in addition to transversal direction. This effect is much 
more pronounced with elevated impregnation time from 4 to $12 \mathrm{~h}$ (Figure $8 \mathrm{~b}$ ).

\section{Conclusion}

The proposed methodology is time consuming, but the traditional FAES determination of $\mathrm{Li}^{+}$in the eluate of slices taken from different depths is precise. The local concentration profiles can be obtained, which may contribute to a deeper understanding of the mass transport in wood. The method could be useful for the calibration of more rapid cation concentration measurements within the wood piece (energy-dispersive X-ray analysis, X-ray fluorescence analysis, secondary ion mass spectrometry, etc.). The method is sensitive and able to detect cracks and other defects influencing the mass transport. All these factors should be considered in the case of precise diffusivity experiments. However, the preliminary results from this study must be further verified by means of more repetitions and experiments performed at higher temperatures.

Acknowledgements: The authors are thankful to the Chalmers Energy Initiative (CEI) program for their financial support.

Received October 31, 2012; accepted February 5, 2013; previously published online March 6, 2013

\section{References}

Behr, E.A., Briggs, D.R., Kaufert, F.H. (1953) Diffusion of dissolved materials through wood. J. Phys. Chem. 57:476-480.

Bengtsson, G., Simonson, R. (1988) Chemimechanical pulping of birch wood chips. Part 2. Studies on impregnation of wood blocks using scanning electron microscopy and energy dispersive X-ray analysis. Nord. Pulp Pap. Res. J. 3:132-137.

Burr, H.K., Stamm, A.J. (1947) Diffusion in wood. J. Phys. Chem. A 51:240-261.

Cady, L.C., Williams, J.W. (1935) Molecular diffusion into wood. J. Phys. Chem. A 39:87-102.

Christensen, G.N. (1951a) Diffusion in wood. II. The temperature coefficient of diffusion through wood. Austral. J. Appl. Sci. 2:430-439.

Christensen, G.N. (1951b) Diffusion in wood. III. Ion selection and its effect on the diffusion of electrolytes. Austral. J. Appl. Sci. 2:440-453.

Christensen, G.N., Williams, E.J. (1951) Diffusion in wood. I. A quantitative theory of diffusion in porous media and its application to wood. Austral. J. Appl. Sci. 2:411-429.

Classen, P.A.M., van Lier, J.B., Lopez Contreras, A.M., van Niel, E.W.J., Sijtsma, L., Stams, A.J.M., de Vries, S.S., Weusthuis, R.A. (1999) Utilization of biomass for the supply of energy carriers. Appl. Microbiol. Biotechnol. 52:741-755.

Cooper, P.A. (1998) Diffusion of copper in wood cell walls following vacuum treatment. Wood Fiber Sci. 30:382-395.

Dautzenberg, G., Gerhardt, M., Kamm, B. (2011) Bio based fuels and fuel additives from lignocellulose feedstock via the production of levulinic acid and furfural. Holzforschung 65:439-451.

Fernando, S., Adhikari, S., Chandrapal, C., Murali, N. (2006) Biorefineries: current status, challenges, and future direction. Energy Fuels 20:1727-1737.

Fukuyama, M., Urakami, H. (1980) Diffusion of nonelectrolytes through wood saturated with water I. Measurements of the diffusion rates by highly sensitive differential refractometer. Mokuzai Gakkaishi 26:587-594.

Fukuyama, M., Urakami, H. (1982) Diffusion of nonelectrolytes through wood saturated with water II. Diffusion rates of the monohydric alcohols. Mokuzai Gakkaishi 28:17-24.
Fukuyama, M., Urakami, H. (1986) Diffusion of nonelectrolytes through wood saturated with water III. Diffusion rates of polyethylene glycols. Mokuzai Gakkaishi 32: 147-154.

Gindl, W., Dessipri, E., Wimmer, R. (2002) Using UV-microscopy to study diffusion of melamine-urea-formaldehyde resin in cell walls of spruce wood. Holzforschung 56:103-107.

Gütsch, J.S., Sixta, H. (2011) Purification of Eucalyptus globulus water prehydrolyzates using the HiTAC process (high-temperature adsorption on activated charcoal). Holzforschung 65:511-518.

Hörhammer, H., Walton, S., van Heiningen, A. (2011) A larch based biorefinery: pre-extraction and extract fermentation to lactic acid. Holzforschung 65:491-496.

Jacobson, A.J., Smith, G.D., Yang, R., Banerjee, S. (2006) Diffusion of sulfide into southern pine (Pinus taeda L.) and sweetgum (Liquidambar styraciflua L.) particles and chips. Holzforschung 60:498-502.

Jyske, T., Mäkinen, H., Saranpää, P. (2008) Wood density within Norway spruce stems. Silva Fennica 42:439-455.

Kazi, K.M.F., Gauvin, H., Jollez, P., Chornet, E. (1997) A diffusion model for the impregnation of lignocellulosic materials. Tappi J. 80:209-219.

Kirsch, C., Zetzl, C., Smirnova, I. (2011) Development of an integrated thermal and enzymatic hydrolysis for lignocellulosic biomass in fixed-bed reactors. Holzforschung 65:483-489.

López, Y., Gullón, B., Puls, J., Parajó, J.C., Martín, C. (2011) Dilute acid pretreatment of starch-containing rice hulls for ethanol production. Holzforschung 65:467-473.

Martin-Sampedro, R., Eugenio, M.E., Revilla, E., Martin, J.A., Villar, J.C. (2011) Integration of Kraft pulping on a forest biorefinery by the addition of a steam explosion pretreatment. Bioresources 6:513-528.

Meijer, M., Zwan, R.P., Militz, H. (1996) Unsteady-state diffusion of methanol in Douglas-fir heartwood at high temperatures. Holzforschung 50:135-143.

Narayanamurti, D., Kumar, V.B. (1953) Diffusion of organic molecules through wood. J. Polym. Sci. 10:515-524. 
Narayanamurti, D., Ratra, R.S. (1951) Diffusion of ions through some Indian timbers. Proc. Indian Acad. Sci. Sect. A 33:349-359.

Näyhä, A., Pesonen, H.-L. (2012) Diffusion of forest biorefineries in Scandinavia and North America. Technol. Forecasting Soc. Change 79:1111-1120.

Ra, J.B., Barnes, H.M., Conners, T.E. (2001) Determination of boron diffusion coefficients in wood. Wood Fiber Sci. 33:90-103.

Ragauskas, A.J., Nagy, M., Kim, D.H., Eckert, C.A., Hallett, J.P., Liotta, C.L. (2006) From wood to fuels: integrating biofuels and pulp production. Ind. Biotech. 2:55-65.

Robertsen, L. Diffusion in wood. Ph.D. thesis. Department of Pulping Technology, Faculty of Chemical Engineering, Åbo Academy, Finland, 1993.

Sandberg, K., Sterley, M. (2009) Separating Norway spruce heartwood and sapwood in dried condition with near-infrared spectroscopy and multivariate data analysis. Eur. For. Res. 128:475-481.

Schütt, F., Puls, J., Saake, B. (2011) Optimization of steam pretreatment conditions for enzymatic hydrolysis of poplar wood. Holzforschung 65:453-459.
Sharareh, S., Tessier, P., Lee, C.-L. (1996) Penetration of sodium sulphite into black spruce and aspen wood chips using SEM/ EDXA. J. Pulp Pap. Sci. 22: J71-J77.

Siau, J.F. Transport processes in wood. Springer Series in Wood Science, vol. 2. Springer-Verlag, Syracuse, 1984.

Stamm, A.J. (1946) Passage of liquids, vapors, and dissolved materials through softwoods. U.S. Dept. Agr. Tech. Bull. 929.

Stone, J.E., Green, H.V. (1959) Penetration and diffusion into hardwoods. Tappi 42:700-709.

Su, P., Granholm, K., Pranovich, A., Harju, L., Holmbom, B., Ivaska, A. (2012) Metal ion sorption to birch and spruce wood. Bioresources 7:2141-2155.

Testova, L., Chong, S.-L., Tenkanen, M., Sixta, H. (2011) Autohydrolysis of birch wood. Holzforschung 65:535-542.

Törnqvist, M., Hurme, T., Rosenholm, J.B. (2001) Drift speed: a way of measuring diffusion and tortuosity of porous materials. Colloids Surf. A Physicochem. Eng. Aspects 180:23-31.

Tsuchikawa, S., Siesler, H.W. (2003) Near-infrared spectroscopic monitoring of the diffusion process of deuterium-labeled molecules in wood. Appl. Spectrosc. 57:675-681. 